\title{
PEMANFAATAN LIMBAH BOTOL PLASTIK (PET) SEBAGAI BAHAN TAMBAH PADA CAMPURAN ASPHALT CONCRETE-WEARING COURSE,
}

\author{
Julius Evandanata ${ }^{1}$, Desriantomy ${ }^{2}$, dan Supiyan ${ }^{3}$ \\ ${ }^{123}$ Program Studi Teknik Sipil, Fakultas Teknik, Universitas Palangka Raya \\ Email: juliusevandanata@gmail.com ${ }^{1}$, desriantomy@yahoo.co.id ${ }^{2}$, \\ supian_ir@yahoo.co.id ${ }^{3} /$ HP: +6285822723252
}

\begin{abstract}
ABSTRAK
Jalan mempunyai peran penting terhadap pembangunan wilayah. Salah satu cara pengembangan jalan adalah dengan meningkatkan kualitas kondisi fisik jalan yang mendukung lancarnya pergerakan transportasi. Upaya untuk mencapai kriteria tersebut dilakukan dengan cara meningkatkan kinerja campuran aspal tersebut, misalnya dengan zat tambah. Penelitian ini mencoba bahan tambah lokal yaitu pemanfaatan limbah botol minuman plastik yang dihancurkan menggunakan alat pencacah berbentuk serpihan-serpihan. Pengujian marshall dilakukan dengan 2 tahap, yaitu Pengujian Marshall I dilakukan untuk mendapatkan nilai Kadar Aspal Optimum (KAO) yang direncanakan dengan variasi kadar aspal 4,5\%, 5\%, 5,5\%, $6 \%$, dan 6,5\%, dan untuk Pengujian Marshall II dilakukan dengan menggunakan $\mathrm{KAO}$ yang diperoleh dari pengujian tahap I dengan penambahan bahan tambah plastik jenis PET dengan variasi kadar 2\%, 4\%, 6\%, 8\%, dan 10\%. Berdasarkan hasil pengujian Marshall I didapat KAO sebesar 5,33\%. Pengujian Marshall II dengan penambahan plastik jenis PET pada variasi kadar bahan tambah yang sudah direncanakan terhadap berat aspal KAO, Parameter Marshall memenuhi spesifikasi, terkecuali nilai Void In Mixture (VIM) pada penambahan kadar plastik sebesar 8\% dan $10 \%$ yang nilainya berturut-turut yaitu 2,79\% dan 2,64\%. Dari hasil evaluasi sifat karakteristik Marshall diperoleh rentang Kadar Plastik Maksimum 0\% hingga 7,9. Penambahan plastik jenis Polyethylene Terepthalate (PET) ternyata memberikan pengaruh pada campuran aspal panas AC-WC dan meningkatkan kualitas karakteristik Marshall.
\end{abstract}

Kata kunci: : ac-wc, polyethylene terepthalate, parameter marshall, kadar aspal optimum

\begin{abstract}
Roads play an important role in regional development. One way of road development is to improve the quality of the physical condition of the road that supports the smooth movement of transportation. Efforts to achieve these criteria are carried out by improving the performance of the asphalt mixture, for example with added substances. This study tried a local added material that is the utilization of waste plastic beverage bottles that are destroyed using a chopping tool in the form of flakes. Marshall testing is carried out in 2 stages, Marshall I Testing is carried out to obtain the planned Optimum Asphalt Content (OAC) value with variations in asphalt levels of $4.5 \%, 5 \%, 5.5 \%, 6 \%$, and $6.5 \%$, and for Marshall II Testing is carried out using OAC obtained from phase I testing with the addition of PET-type plastic-added materials with variations of $2 \%, 4 \%, 6 \%, 8 \%$, and $10 \%$. Based on Marshall I test results obtained OAC by 5.33\%. Marshall II testing with
\end{abstract}


the addition of PET type plastic in the variation of material added content that has been planned to the weight of OAC, Marshall Parameters meet the specifications, except VIM value at the addition of plastic content of $8 \%$ and $10 \%$ whose value is $2.79 \%$ and $2.64 \%$ respectively. From the evaluation of marshall characteristic properties obtained a maximum plastic content range of $0 \%$ to 7.9. The addition of PET type plastic turns out to have an influence on ac-wc hot asphalt mixture and improve the quality of Marshall characteristics.

Keywords: ac-wc, polyethylene terephthalate, marshall parameters, optimum asphalt content

\section{PENDAHULUAN}

Jalan sebagai bagian dari prasarana perhubungan darat mempunyai peranan yang sangat penting terhadap pembangunan dan pengembangan wilayah. Sebagai salah satu cara pengembangan jalan adalah dengan meningkatkan kualitas kondisi fisik jalan yang mendukung lancarnya pergerakan transportasi. Kondisi fisik jalan dapat ditingkatkan dengan merencanakan kualitas jalan yang diinginkan sedemikian rupa sehingga tahan terhadap kerusakan-kerusakan yang timbul di permukaan jalan akibat hantaman, gesekan beban roda kendaraan yang lewat di atasnya dan cuaca. Upaya untuk mencapai kriteria tersebut dapat dilakukan dengan cara meningkatkan kinerja campuran aspal tersebut, misalnya dengan zat tambah (additive). Bahan tambah (additive) yang sering digunakan seperti aboccel, roadcel, cellulose, fibres, tafpack-super merupakan bahan tambah yang harganya masih relatif mahal sehingga secara keseluruhan kurang ekonomis, untuk itu perlu dicari suatu material yang sedapat mungkin bisa merupakan produk lokal dan ekonomis.

Penelitian ini mencoba bahan tambah lokal yaitu berupa pemanfaatan limbah botol minuman plastik sekali pakai yang dihancurkan sedemikian rupa sehingga berbentuk serpihan-serpihan. Karena limbah botol minuman plastik sekali pakai merupakan bahan buangan yang tentunya akan menimbulkan masalah bagi lingkungan jika tidak dikelola dengan baik. Bila material ini dapat digunakan sebagai bahan tambah pada campuran aspal jenis asphalt concrete-wearing course (ac-wc) maka banyak masalah sekaligus dapat terpecahkan. Dari hasil penelitian ini diharapkan diperoleh alternatif bahan tambah (additive) yang murah serta mudah didapat dibanding dengan bahan tambah (additive) yang sering digunakan, sehingga dapat membantu memecahkan masalah-masalah yang terjadi pada perkerasan jalan. Pada penelitian ini plastik PET (polyethylene terephthalate) dicacah dengan alat pencacah membentuk serpihan-serpihan dengan ukuran panjang dan lebar kurang dari $1 \mathrm{~cm}$ atau $100 \%$ lolos saringan 3/8" dan $90 \%$ lolos saringan No. 4. 


\section{TINJAUAN PUSTAKA}

\section{Botol Minuman Plastik}

Plastik PET (polyethylene terephthalate) merupakan polimer jernih dan kuat dengan sifat-sifat penahan gas dan kelembapan. Kemampuan plastik PET untuk menampung karbon dioksida (karbonasi) membuatnya sangat ideal untuk digunakan sebagai botol-botol minuman ringan (bersoda/terkarbonasi). Selain itu plastik PET juga sering digunakan sebagai botol air minum kemasan. plastik PET (polyethylene terephthalate) lahir pada tahun 1973, dan pertama kali didaur-ulang pada tahun 1977. PET merupakan resin polyester yang tahan lama, kuat, ringan dan mudah dibentuk ketika panas. Kepekatannya adalah sekitar 1,35-1,38 gram/cc, ini membuatnya kokoh. Plastik PET (polyethylene terephthalate) dapat berwujud padatan amorf (transparan) atau sebagai bahan semi-kristal yang putih dan tidak transparan, tergantung kepada proses dan riwayat termalnya. (Fitria, 2014)

\section{METODE PENELITIAN}

Penelitian ini menggunakan metode uji laboratorium. Sebelum digunakan, material terlebih dahulu dilakukan pemeriksaan terhadap agregat di laboratorium untuk mendapatkan karakteristik masing-masing material tersebut. Data hasil pengamatan di laboratorium selanjutnya digunakan untuk perencanaan campuran. Selanjutnya dapat diketahui karakteristik campuran tersebut. Guna mempermudah pemahaman mengenai proses alur penelitian, dapat dilihat pada Gambar 1.

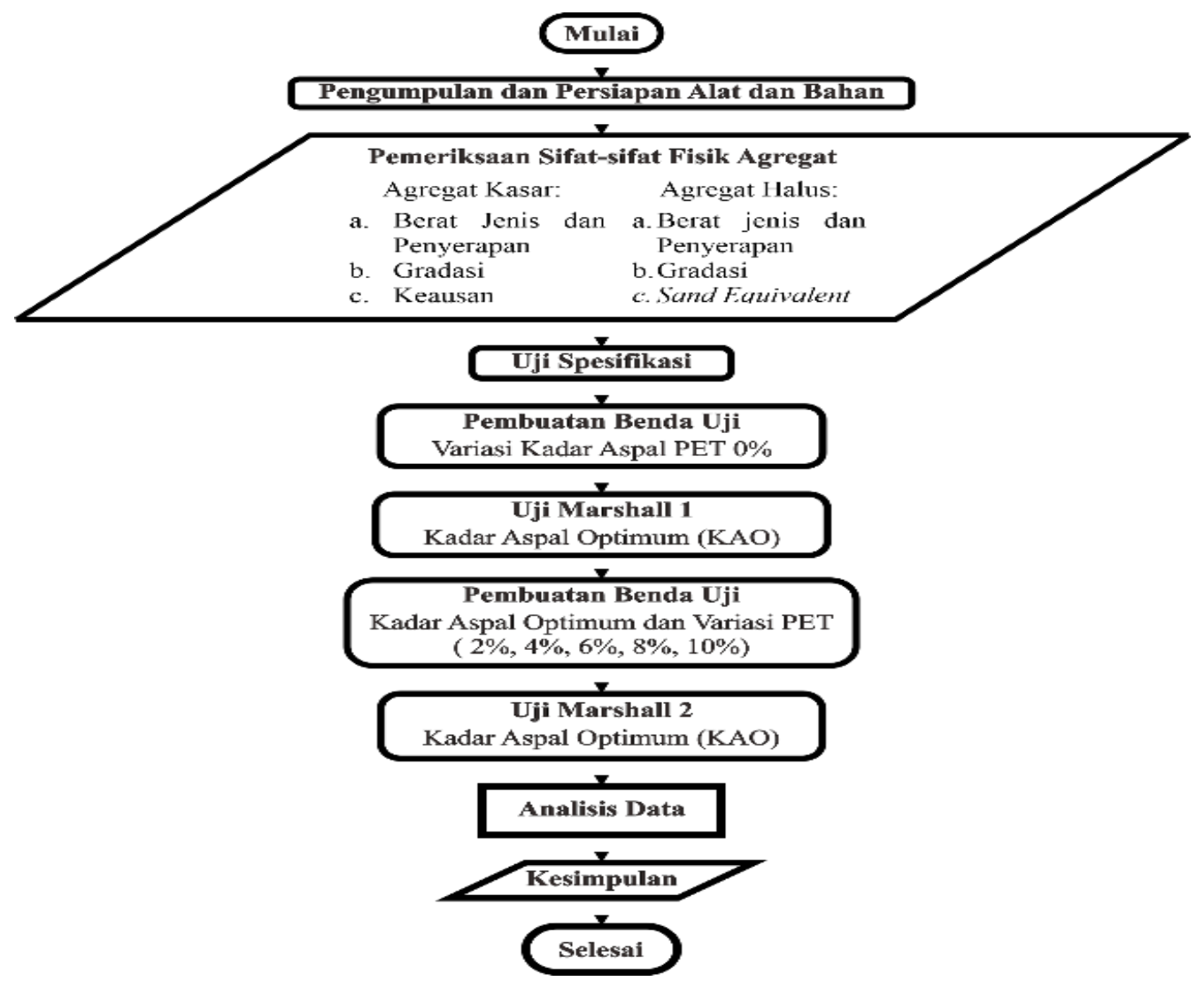

Gambar 1. Bagan Alir Penelitian 


\section{HASIL ANALISIS DAN PEMBAHASAN}

\section{Perencanaan Sifat Fisik Agregat}

Pengujian sifat-sifat fisik agregat terdiri dari pengujian gradasi agregat, pengujian berat jenis dan penyerapan agregat, pengujian keausan (abrasi) agregat kasar dan pengujian kadar lempung agregat halus (sand equivalent). Pemeriksaan gradasi agregat kasar dan agregat halus dilakukan dengan uji analisa saringan yang hasilnya dapat dilihat pada Tabel 1. Selain itu, pemeriksaan sifat-sifat fisik agregat yaitu pemeriksaan berat jenis, penyerapan dan keausan (abrasi) dapat dilihat pada Tabel 2.

Tabel 1. Hasil Analisa Masing-Masing Agregat

\begin{tabular}{|c|c|c|c|c|}
\hline \multirow{2}{*}{ Ukuran Saringan } & \multicolumn{3}{|c|}{ Eks. Tangkiling } \\
\cline { 3 - 5 } & & \multicolumn{3}{|c|}{ Persentase Lolos Saringan (\%) } \\
\hline Inch & Mm & Agregat Kasar & Abu Batu & Agregat Halus \\
\hline$\# 1$ & 25,4 & 100,00 & 100,00 & 100,00 \\
\hline$\# 3 / 4$ & 19,05 & 100,00 & 100,00 & 100,00 \\
\hline$\# 1 / 2$ & 12,7 & 67,07 & 100,00 & 100,00 \\
\hline$\# 3 / 8$ & 9,53 & 34,33 & 97,04 & 100,00 \\
\hline No.4 & 4,75 & 6,23 & 62,23 & 98,61 \\
\hline No.8 & 2,35 & 3,80 & 19,57 & 83,57 \\
\hline No.16 & 1,18 & 2,11 & 11,61 & 53,07 \\
\hline No.30 & 0,6 & 0,92 & 6,01 & 35,39 \\
\hline No.50 & 0,3 & 0,45 & 2,85 & 25,14 \\
\hline No.100 & 0,15 & 0,28 & 1,56 & 18,27 \\
\hline No.200 & 0,075 & 0,10 & 0,66 & 8,92 \\
\hline
\end{tabular}

Sumber : Analisis Data (2020)

Tabel 2. Hasil Pemeriksaan Sifat-Sifat Masing-Masing Agregat

\begin{tabular}{|c|c|c|c|c|}
\hline \multirow[b]{2}{*}{ Pemeriksaan } & \multicolumn{3}{|c|}{ Eks. Tangkiling } & \multirow{2}{*}{$\begin{array}{c}\text { Spesifikas } \\
\text { i }\end{array}$} \\
\hline & $\begin{array}{l}\text { Agregat } \\
\text { Kasar }\end{array}$ & Abu Batu & Pasir & \\
\hline Berat Jenis Bulk (gram/cm³) & 2,66 & 2,68 & 2,56 & - \\
\hline $\begin{array}{l}\text { Berat Jenis Kering Permukaan } \\
\text { Jenuh/SSD }\left(\text { gram } / \mathrm{cm}^{3}\right)\end{array}$ & 2,70 & 2,71 & 2,62 & - \\
\hline Berat Jenis Semu $\left(\mathrm{gram} / \mathrm{cm}^{3}\right)$ & 2,75 & 2,74 & 2,72 & - \\
\hline Penyerapan $(\%)$ & 1,21 & 0,80 & 2,21 & $\operatorname{Max} 3 \%$ \\
\hline Keausan/Abrasi (\%) & 25,69 & - & - & $\operatorname{Max} 30 \%$ \\
\hline Sand Equivalent (\%) & - & - & 68,83 & Min $50 \%$ \\
\hline
\end{tabular}

Sumber : Analisis Data (2020)

Perencanaan campuran untuk Komposisi ini menggunakan metode Asphalt Institute dan perhitungan penggabungan agregat menggunakan cara Diagonal. Selanjutnya gradasi agregat gabungan dikontrol menggunakan cara coba-coba (trial and error) atau yang mendekati spesifikasi ideal. Hasil dari cara coba-coba ini dapat dilihat dalam Tabel 3. 
Tabel 3. Hasil Perhitungan Gradasi Gabungan Cara Coba-Coba (Trial and Error)

\begin{tabular}{|c|c|c|c|c|c|c|c|c|c|c|}
\hline \multicolumn{2}{|c|}{ No. Saringan } & \multirow{2}{*}{\multicolumn{2}{|c|}{$\begin{array}{c}\begin{array}{c}\text { Agregat } \\
\text { Kasar }\end{array} \\
26 \%\end{array}$}} & \multirow{2}{*}{\multicolumn{2}{|c|}{$\begin{array}{c}\begin{array}{c}\text { Agregat } \\
\text { Halus (Abu } \\
\text { Batu) }\end{array} \\
\mathbf{3 1 \%}\end{array}$}} & \multirow{2}{*}{\multicolumn{2}{|c|}{\begin{tabular}{|c|}
$\begin{array}{c}\text { Agregat Halus } \\
\text { (Pasir) }\end{array}$ \\
$43 \%$ \\
\end{tabular}}} & \multirow{3}{*}{$\begin{array}{c}\begin{array}{c}\text { Total } \\
\text { Kombinasi }\end{array} \\
100,00 \\
\end{array}$} & \multirow{3}{*}{\begin{tabular}{|c|} 
Spesifikasi \\
100,00 \\
\end{tabular}} & \multirow{3}{*}{$\begin{array}{r}\begin{array}{r}\text { Ideal } \\
\text { Spek }\end{array} \\
100 \\
\end{array}$} \\
\hline \multirow{2}{*}{$\begin{array}{c}\text { Inch } \\
\# 1\end{array}$} & \multirow{2}{*}{$\begin{array}{l}\mathbf{M m} \\
25,4\end{array}$} & & & & & & & & & \\
\hline & & 100,00 & 26,00 & 100,00 & 31,00 & 100,00 & 43,00 & & & \\
\hline$\# 3 / 4$ & 19 & 100,00 & 26,00 & 100,00 & 31,00 & 100,00 & 43,00 & 100,00 & 100,00 & 100 \\
\hline$\# 1 / 2$ & 12,7 & 67,07 & 17,44 & 100,00 & 31,00 & 100,00 & 43,00 & 91,44 & $90-100$ & 95 \\
\hline$\# 3 / 8$ & 9,5 & 34,33 & 8,93 & 97,04 & 30,08 & 100,00 & 43,00 & 82,01 & $77-90$ & 83,5 \\
\hline No.4 & 4,75 & 6,23 & 1,62 & 62,23 & 19,29 & 98,61 & 42,40 & 63,31 & $53-69$ & 61 \\
\hline No. 8 & 2,38 & 3,80 & 0,99 & 19,57 & 6,07 & 83,97 & 36,10 & 43,16 & $33-53$ & 43 \\
\hline No.16 & 1,18 & 2,11 & 0,55 & 11,61 & 3,60 & 53,07 & 22,82 & 26,97 & $21-40$ & 30,5 \\
\hline No.30 & 0,595 & 0,92 & 0,24 & 6,01 & 1,86 & 35,39 & 15,22 & 17,32 & $14-30$ & 22 \\
\hline No.50 & 0,3 & 0,45 & 0,12 & 2,85 & 0,88 & 25,14 & 10,81 & 11,81 & $9-22$ & 15,5 \\
\hline No.100 & 0,15 & 0,28 & 0,07 & 1,56 & 0,48 & 18,27 & 7,85 & 8,41 & $6-15$ & 10,5 \\
\hline No.200 & 0,074 & 0,10 & 0,03 & 0,66 & 0,20 & 8,92 & 3,83 & 4,07 & $4-9$ & 6,5 \\
\hline
\end{tabular}

Sumber : Analisis Data (2020)

Dari hasil perhitungan komposisi campuran yang telah didapatkan, nilai total kombinasi dapat digunakan untuk menentukan perkiraan kadar aspal awal. Perkiraan kadar aspal awal diperoleh dengan menggunakan Persamaan 1.

$\mathrm{Pb}=0,035(\% \mathrm{CA})+0,045(\% \mathrm{FA})+0,18(\%$ Filler $)+$ Konstanta

Keterangan:

$\mathrm{Pb} \quad=$ Kadar aspal

$\mathrm{CA} \quad=$ Agregat kasar (Course Aggregate)

FA = Agregat halus (Fine Aggregate)

Filler = Agregat halus lolos saringan No. 200

Konstanta $=$ 0,5-1 (untuk AC-WC diambil nilai konstanta $=1$ )

Dengan menggunakan persamaan diatas maka diperoleh nilai kadar aspal $\mathrm{Pb}=$ 5,52\% atau dibulatkan menjadi 5,5\% yang kemudian diurutkan dua variasi Kadar Aspal ke bawah dan dua variasi Kadar Aspal ke atas dengan interval 0,5\%. Dari hasil perhitungan perkiraan Kadar Aspal diperoleh lima variasi Kadar Aspal yaitu $4,5 \%, 5 \%, 5,5 \%, 6 \%$, dan 6,5\%. Persentase terhadap berat total agregat yang digunakan yaitu 1200 gram.

Rancangan berat material dan aspal dalam campuran berdasarkan Komposisi yang telah ditetapkan dapat dilihat pada Tabel 4 berikut ini 
Tabel 4. Rancangan Komposisi Campuran

\begin{tabular}{|c|c|c|c|c|c|c|c|c|c|c|c|}
\hline \multicolumn{6}{|c|}{ Berat Total Agregat 1200 gram } & \multirow{3}{*}{$\begin{array}{c}\text { Berat Total } \\
\text { Agregat } \\
\text { Campuran }\end{array}$} & \multicolumn{5}{|c|}{ Variasi Kadar Aspal (\%) } \\
\hline \multirow{2}{*}{\multicolumn{2}{|c|}{$\begin{array}{c}\text { Agregat } \\
\text { Kasar } \\
\text { (CA) }\end{array}$}} & \multirow{2}{*}{\multicolumn{2}{|c|}{$\begin{array}{c}\text { Agregat } \\
\text { Sedang } \\
\text { (MA) }\end{array}$}} & \multirow{2}{*}{\multicolumn{2}{|c|}{$\begin{array}{c}\text { Agregat } \\
\text { Halus } \\
\text { (FA) }\end{array}$}} & & 4,5 & $\mathbf{5 , 0}$ & $\mathbf{5 , 5}$ & 6,0 & 6,5 \\
\hline & & & & & & & \multicolumn{5}{|c|}{$\begin{array}{c}\text { Berat Kadar Aspal Terhadap Total } \\
\text { Campuran }\end{array}$} \\
\hline$\%$ & gr & $\%$ & gr & $\%$ & gr & gr & \multicolumn{5}{|c|}{ gr } \\
\hline 24 & 288 & 31 & 372 & 45 & 540 & 1200 & 56,54 & 63,15 & 69,84 & 76,59 & 83,42 \\
\hline
\end{tabular}

\section{Pengujian Marshall}

Hasil dari pengujian Marshall I di Laboratorium dapat dilihat pada Tabel 5. Dari hasil pengujian Marshall I ini menunjukkan bahwa pada kadar aspal 4,5\% (VIM lebih dari 5\%), 6\% dan 6,5\% (VIM kurang dari 3\%) maka campuran aspal pada persentase tersebut tidak memenuhi Spesifikasi Parameter Marshall, sedangkan pada kadar aspal 5\% dan 5,5\% memenuhi Spesifikasi Parameter Marshall.

Tabel 5. Hasil Pengujian Parameter Karakteristik Marshall I

\begin{tabular}{|c|c|c|c|c|c|}
\hline \multirow{2}{*}{$\begin{array}{c}\text { Kadar } \\
\text { Aspal } \\
(\%)\end{array}$} & $\begin{array}{c}\text { Stabilitas } \\
(\mathbf{k g})\end{array}$ & $\begin{array}{c}\text { Flow } \\
(\mathbf{m m})\end{array}$ & $\begin{array}{c}\text { Rongga Dalam } \\
\text { Campuran } \\
(\text { VIM) }(\%)\end{array}$ & $\begin{array}{c}\text { Rongga } \\
\text { Terisi Aspal } \\
(\text { VFB) }(\%)\end{array}$ & Keterangan \\
\hline 4,5 & 1182,501 & 3,170 & 5,220 & 65,758 & VIM Tidak Memenuhi \\
\hline 5 & 1219,568 & 3,130 & 4,918 & 79,391 & Memenuhi \\
\hline 5,5 & 1267,416 & 3,230 & 3,741 & 76,816 & Memenuhi \\
\hline 6 & 1220,563 & 3,300 & 2,508 & 84,547 & VIM Tidak Memenuhi \\
\hline 6,5 & 1134,405 & 3,370 & 2,543 & 85,316 & VIM Tidak Memenuhi \\
\hline Spek. & $\geq 800$ & $2-4$ & $3-5$ & $\geq 65$ & \multicolumn{1}{|c}{} \\
\hline
\end{tabular}

Sumber : Analisi Data (2020)

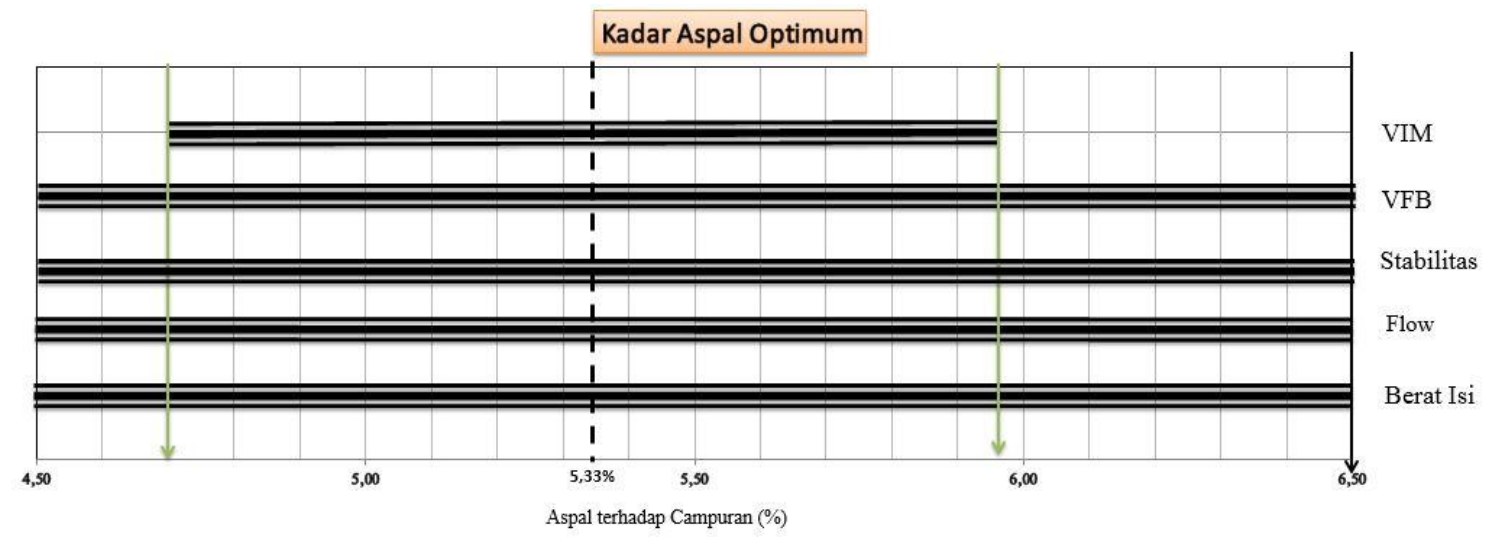

Gambar 2. Hubungan Nilai Parameter Marshall Terhadap Kadar Aspal Optimum (KAO)

Hasil evaluasi sifat fisik menunjukkan bahwa pada rentang kadar aspal 5,00\% hingga 6,00\% untuk (VIM) campuran memenuhi semua persyaratan yang ditentukan. Dan berdasarkan rentang kadar aspal 4,70\% hingga 5,96\% memenuhi spesifikasi parameter Marshall dan diambil nilai tengah rentang yaitu 5,33\% 
sebagai KAO. Dari hasil pengujian maka didapat hasil evaluasi sifat Marshall pada KAO 5,33\% dapat dilihat pada Tabel 6.

Tabel 6. Nilai Parameter Karakteristik Marshall pada Kadar Aspal Optimum (KAO)

\begin{tabular}{|c|l|c|c|c|}
\hline No. & Sifat Marshall & Nilai & Persyaratan & Satuan \\
\hline 1 & Stabilitas & 1254 & $\geq 800$ & $\mathrm{~kg}$ \\
\hline 2 & Flow & 3,21 & $2-4$ & $\mathrm{~mm}$ \\
\hline 3 & VIM & 4,10 & $3-5$ & $\%$ \\
\hline 4 & VFB & 75 & $\geq 65$ & $\%$ \\
\hline
\end{tabular}

Sumber : Analisis Data (2020)

\section{Pengujian Marshall dengan Variasi Bahan Tambah Plastik Jenis Polythylene Terepthalate (PET)}

Setelah diperoleh nilai Kadar Aspal Optimum (KAO), dilakukan penelitian dengan menggunakan bahan tambah plastik bekas jenis Polyethylene Terepthalate (PET) dengan menggunakan komposisi agregat yang sama dengan KAO dan dengan variasi kadar bahan tambah yang sudah direncanakan. Rancangan komposisi campuran ini dapat dilihat pada Tabel 7.

Tabel 7. Rancangan Komposisi Campuran dengan Variasi Persentase Bahan Tambah Plastik Jenis Polyethylene Terepthalate (PET)

\begin{tabular}{|c|c|c|c|c|c|c|}
\hline $\begin{array}{c}\text { Berat } \\
\text { Total } \\
\begin{array}{c}\text { Agregat } \\
\text { Campuran }\end{array}\end{array}$ & \multicolumn{2}{|c|}{$\begin{array}{c}\text { Berat KAO } \\
\text { Terhadap Total } \\
\text { Campuran }\end{array}$} & $\begin{array}{c}\text { Persentase } \\
\text { Plastik } \\
\text { terhadap } \\
\text { Berat Aspal } \\
\text { (KAO) }\end{array}$ & $\begin{array}{c}\text { Berat } \\
\text { Plastik } \\
\text { terhadap } \\
\text { Berat Aspal } \\
\text { (KAO) }\end{array}$ & $\begin{array}{c}\text { Berat } \\
\text { Total } \\
\text { Campuran }\end{array}$ & $\begin{array}{c}\text { Kode } \\
\text { Sampel }\end{array}$ \\
\hline gram & $\%$ & gram & $\%$ & Gram & Gram & \\
\hline 1200 & 5,33 & 73,96 & 2,00 & 1,27 & 1275,43 & B \\
\hline 1200 & 5,33 & 73,96 & 4,00 & 2,55 & 1276,91 & C \\
\hline 1200 & 5,33 & 73,96 & 6,00 & 3,83 & 1278,39 & D \\
\hline 1200 & 5,33 & 73,96 & 8,00 & 5,11 & 1279,87 & E \\
\hline 1200 & 5,33 & 73,96 & 10,00 & 6,39 & 1281,35 & F \\
\hline
\end{tabular}

Sumber : Analisis Data (2020)

Tabel 8. Hasil Pengujian Karakteristik Marshall Pada KAO dengan Variasi Bahan Tambah Platik Jenis Polyethylene Terepthalate (PET)

\begin{tabular}{|c|c|c|c|c|c|}
\hline $\begin{array}{c}\text { Kadar } \\
\text { Plastik } \\
\text { terhadap } \\
\text { Berat } \\
\text { Aspal (\%) }\end{array}$ & $\begin{array}{c}\text { Stabilitas } \\
(\mathrm{kg})\end{array}$ & $\begin{array}{c}\text { Flow } \\
(\mathrm{mm})\end{array}$ & $\begin{array}{c}\text { Rongga } \\
\text { Dalam } \\
\text { Campuran } \\
(\mathrm{VIM})(\%)\end{array}$ & $\begin{array}{c}\text { Rongga } \\
\text { Terisi } \\
\text { Aspal } \\
(\mathrm{VFB}) \\
(\%)\end{array}$ & Keterangan \\
\hline 0,0 & 1254,00 & 2,90 & 4,10 & 75,00 & $\begin{array}{c}\text { Hasil Marshall I } \\
\text { Komposisi II }\end{array}$ \\
\hline 2,0 & 1284,33 & 3,23 & 3,82 & 75,88 & Memenuhi \\
\hline 4,0 & 1342,79 & 3,30 & 3,82 & 75,85 & Memenuhi \\
\hline 6,0 & 1360,70 & 3,40 & 3,44 & 77,79 & Memenuhi \\
\hline
\end{tabular}


JURNAL KACAPURI

JURNAL KEILMUAN TEKNIK SIPIL

Volume 4 Nomor 1 Edisi Juni 2021

\begin{tabular}{|c|c|c|c|c|c|}
8,0 & 1453,00 & 3,60 & 2,79 & 81,30 & VIM Tidak Memenuhi \\
\hline 10,0 & 1497,94 & 3,87 & 2,64 & 82,17 & VIM Tidak Memenuhi \\
\cline { 1 - 4 } Spek. & $\geq 800$ & $2-4$ & $3-5$ & $\geq 65$ & \multicolumn{1}{|c}{} \\
\cline { 1 - 4 }
\end{tabular}

Sumber : Analisis Data (2020)

Dari Tabel 8 hasil pengujian Marshall II ini menunjukan bahwa pada penambahan plastik ke dalam campuran pada persentase $2 \%, 4 \%$ dan $6 \%$ terhadap berat aspal dari KAO, campuran aspal tersebut sudah memenuhi Spesifikasi Parameter Marshall pada Spesifikasi Umum Bina Marga Divisi 6 Perkerasan Aspal (2018). Sedangkan untuk penambahan plastik persentase $8 \%$ dan $10 \%$, nilai parameter karakteristik Marshall dari rongga dalam campuran (VIM) tidak memenuhi Spesifikasi. Nilai rongga dalam campuran (VIM) untuk persentase bahan tambah $8 \%$ dan $10 \%$ berturut-turut yaitu sebesar $2,79 \%$ dan 2,64\%, dibawah nilai yang disyaratkan dari Spesifikasi Umum Bina Marga Divisi 6 Perkerasan Aspal (2018)

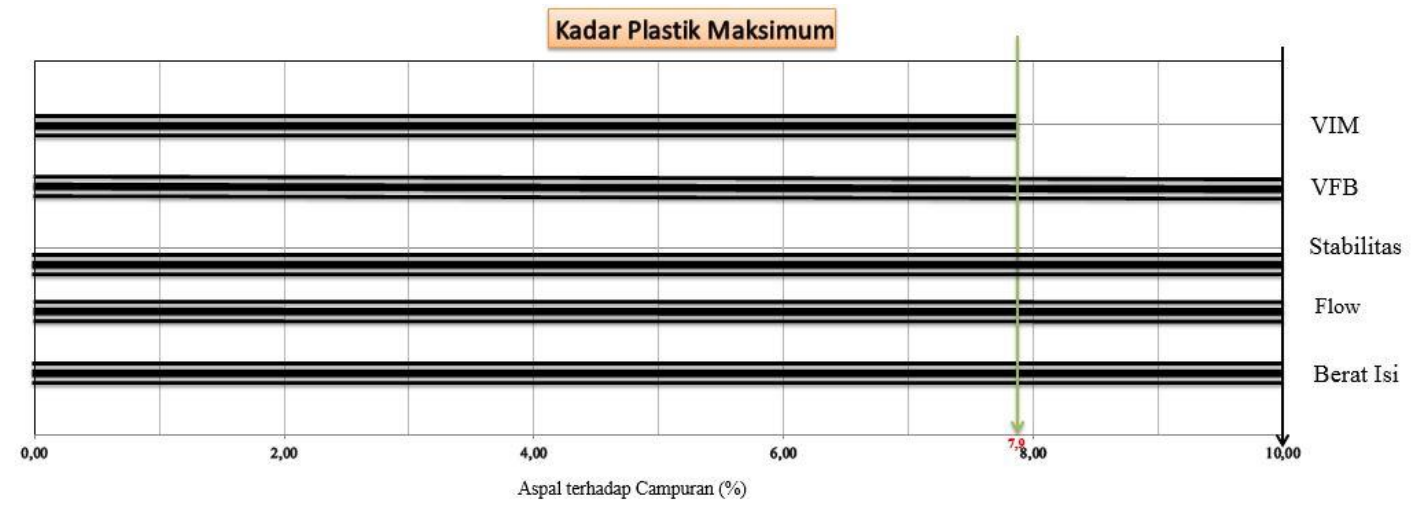

yaitu nilai rongga dalam campuran (VIM) sebesar 3\% - 5\%.

Gambar 3. Hubungan Nilai Parameter Aspal terhadap Kadar Penambahan Plastik

Tabel 9. Nilai Parameter Marshall pada Kadar Plastik Maksimum

\begin{tabular}{|c|l|c|c|c|}
\hline No. & Sifat Marshall & Nilai & Persyaratan & Satuan \\
\hline 1 & Stabilitas & 1440 & $\geq 800$ & $\mathrm{~kg}$ \\
\hline 2 & Flow & 2,77 & $2-4$ & $\mathrm{~mm}$ \\
\hline 3 & VIM & 3,15 & $3-5$ & $\%$ \\
\hline 4 & VFB & 81,21 & $\geq 65$ & $\%$ \\
\hline
\end{tabular}

Sumber : Analisis Data (2020)

Hasil evaluasi sifat karakteristik Marshall menunjukan bahwa rentang penambahan kadar plastik persentase $0 \%$ hingga $7,9 \%$ campuran memenuhi semua persyaratan yang ditentukan. Berdasarkan rentang tersebut diambil nilai kadar penambahan plastik maksimum dilihat dari nilai parameter Marshall memenuhi semua persyaratan spesifikasi yang telah ditentukan dan dilihat dari nilai stabilitas tertinggi, yaitu pada kadar penambahan plastik sebesar $7,9 \%$ sehingga dapat ditetapkan sebagai kadar bahan tambah optimum.

Dapat dilihat dari Tabel 9 bahwa nilai parameter karakteristik Marshall dari Kadar Plastik Maksimum memiliki stabilitas sebesar $1440 \mathrm{~kg}$, flow sebesar 2,77 mm, 
rongga dalam campuran (VIM) sebesar 3,15\%, dan rongga terisi aspal (VFB) sebesar $81,21 \%$.

Tabel 10. Perbandingan Nilai Parameter Marshall Campuran Tanpa Plastik dan Menggunakan Kadar Penambahan Plastik Maksimum

\begin{tabular}{|c|c|c|c|c|c|}
\hline \multirow{2}{*}{$\begin{array}{c}\text { Komposisi } \\
\text { Campuran }\end{array}$} & $\begin{array}{c}\text { Kadar } \\
\text { Plastik }\end{array}$ & $\begin{array}{c}\text { Stabilitas } \\
(\mathrm{kg})\end{array}$ & $\begin{array}{c}\text { Flow } \\
(\mathrm{mm})\end{array}$ & $\begin{array}{c}\text { Rongga } \\
\text { dalam } \\
\text { Campuran } \\
(\%)\end{array}$ & $\begin{array}{c}\text { Rongga } \\
\text { Terisi } \\
\text { Aspal (\%) }\end{array}$ \\
\hline Tanpa Plastik & 0,00 & 1254,00 & 2,90 & 4,10 & 75,00 \\
\hline $\begin{array}{c}\text { Kadar Plastik } \\
\text { Optimum }\end{array}$ & 7,9 & 1440,00 & 2,77 & 3,15 & 81,21 \\
\hline Spesifikasi & - & $\geq 800$ & $2-4$ & $4-6$ & $\geq 65$ \\
\hline
\end{tabular}

Sumber : Analisis Data (2020)

Dari tabel di atas dapat dilihat bahwa penambahan plastik jenis Polyethylene Terepthalate (PET) sebesar 7,9\% dari berat aspal KAO, nilai stabilitas naik $12,916 \%$ dari nilai stabilitas campuran tanpa menggunakan bahan tambah plastik yaitu mengalami kenaikan sebesar $186 \mathrm{~kg}$, nilai flow naik sebesar $0,28 \mathrm{~mm}$, rongga dalam campuran (VIM) turun sebesar $0,95 \%$, dan rongga terisi aspal (VFB) naik sebesar $6,21 \%$.

\section{PENUTUP}

\section{Kesimpulan}

Berdasarkan hasil penelitian dan pembahasan yang telah diuraikan sebelumnya, pada "Pemanfaatan Limbah Kemasan Botol Minuman Plastik Sebagai Bahan Tambah pada Campuran Aspal Panas Jenis Asphalt Concrete-Wearing Course (ACWC)" Terhadap Karakteristik Marshall" dapat disimpulkan beberapa hal sebagai berikut:

1. Agregat penyusun dalam perencanaan campuran Asphalt Concrete-Wearing Course (AC-WC) dari hasil pemeriksaan sifat-sifat fisik agregat berupa pemeriksaan gradasi (analisa saringan), berat jenis dan penyerapan, dan keausan agregat kasar semuanya memenuhi persyaratan spesifikasi.

2. Komposisi yang dihasilkan dalam perencanaan campuran Asphalt ConcreteWearing Course (AC-WC) terdiri dari $28 \%$ agregat kasar, $31 \%$ abu batu dan $41 \%$ Pasir.

3. Hasil penelitian terhadap Parameter Marshall dengan variasi kadar aspal 4,5\%, $5 \%, 5,5 \%, 6 \%$, dan 6,5\% diperoleh Kadar Aspal Optimum (KAO) senilai $5,33 \%$.

4. Hasil penelitian terhadap Parameter Karakteristik Marshall menggunakan komposisi campuran yang sama dan Kadar Aspal Optimum (KAO) senilai 5,33\% dengan bahan tambah plastik jenis Polyethylene Terepthalate (PET), variasi kadar bahan tambah plastik sebesar 0\%, 2\%, 4\%, 6\%, 8\% dan 10\% dari berat aspal yang diperoleh dari Kadar Aspal Optimum (KAO), dihasilkan nilai Karakteristik Parameter Marshall sebagai berikut: 
a. Nilai stabilitas untuk semua variasi kadar bahan tambah plastik memenuhi spesifikasi yang disyaratkan. Nilai stabilitas tertinggi terdapat pada penambahan kadar plastik $10 \%$ yaitu sebesar 1497,94 kg. Nilai Stabilitas yang dihasilkan meningkat seiring dengan penambahan persentase kadar plastik sampai $10 \%$.

b. Nilai kelelehan (flow) untuk semua variasi kadar bahan tambah plastik memenuhi spesifikasi yang disyaratkan. Nilai kelelehan (flow) tertinggi terdapat pada penambahan kadar plastik $10 \%$ yaitu sebesar $3,87 \mathrm{~mm}$. Nilai flow meningkat seiring dengan penambahan persentase kadar plastik sampai $10 \%$.

c. Nilai rongga udara dalam campuran (VIM) untuk variasi kadar bahan tambah plastik $0 \%, 2 \%, 4 \%$ dan $6 \%$ memenuhi spesifikasi dan untuk variasi kadar bahan tambah plastik $8 \%$ dan $10 \%$ tidak memenuhi spesifikasi. Nilai VIM tertinggi yang memenuhi spesifikasi pada kadar penambahan plastik $0 \%$, yaitu sebesar $4,01 \%$. Nilai rongga dalam campuran (VIM) yang dihasilkan cenderung menurun dengan penambahan persentase kadar plastik sampai $10 \%$.

d. Nilai rongga terisi aspal (VFB) untuk semua variasi kadar bahan tambah plastik memenuhi spesifikasi yang disyaratkan. Nilai rongga terisi aspal (VFB) tertinggi terdapat pada penambahan kadar plastik $10 \%$ yaitu sebesar $81,17 \%$. Nilai rongga terisi aspal meningkat seiring dengan penambahan persentase kadar plastic sampai $10 \%$.

5. Berdasarkan hasil penelitian terhadap parameter karakteristik Marshall dengan variasi kadar bahan tambah plastik bekas jenis Polyethylene Terepthalate (PET) yang sudah dilakukan, dibuat grafik hubungan antara parameter Marshall campuran aspal dengan persentase kadar bahan tambah yang digunakan untuk menentukan nilai kadar plastik maksimum. Didapatkan kadar penambahan plastik optimum sebesar 7,9\%. Nilai parameter karakteristik Marshall pada Kadar Aspal Optimum (KAO) dan penambahan plastik pada kadar plastik optimum menghasilkan stabilitas sebesar $1440 \mathrm{~kg}$, flow sebesar 2,77 mm, rongga dalam campuran (VIM) sebesar 3,15\%, dan rongga terisi aspal (VFB) sebesar $81,21 \%$.

6. Plastik jenis Polyethylene Terepthalate (PET) dari kadar penambahan plastik maksimum sebesar 7,9\% dari berat aspal, dapat mempengaruhi parameter karakteristik Marshall nilai stabilitas naik 12,916\% dari nilai stabilitas campuran tanpa menggunakan bahan tambah plastik yaitu mengalami kenaikan sebesar $186 \mathrm{~kg}$, nilai flow naik sebesar $0,28 \mathrm{~mm}$, rongga dalam campuran (VIM) turun sebesar $0,95 \%$, dan rongga terisi aspal (VFB) naik sebesar $6,21 \%$,

\section{Saran}

Setelah melakukan penelitian ini, dapat disampaikan beberapa saran sebagai berikut:

1. Penelitian ini bisa dikembangkan kembali dengan menggunakan Agregat dari lokasi yang berbeda khususnya di Kalimantan Tengah untuk meningkatkan potensi Sumber Daya Alam yang ada. 
2. Ukuran cacahan plastik yang akan ditambahkan pada campuran aspal dan agregat harus sesuai dengan spesifikasi yang digunakan agar dapat diharapkan plastik tercampur merata untuk menghindari plastik menghalangi aspal menyelimuti agregat.

3. Penelitian ini dapat dilakukan penelitian kembali dengan jenis plastik yang berbeda karena terdapat jenis plastik lain selain jenis Polyethylene Terepthalate (PET) yang dapat diteliti sebagai bahan tambah pada campuran aspal.

\section{DAFTAR PUSTAKA}

1. Anonim. (2018), Penerapan Skala Penuh Teknologi Aspal Limbah Plastik, Balitbang dan BBPJN VIII, Surabaya.

2. Anonim. (2018), Spesifikasi Umum Devisi 6 Bina Marga. Jakarta: Direktorat Jendral Bina Marga.

3. Azhari, W. (2017), Pengaruh Variasi Suhu Pemadatan Terhadap Campuran Hot Rolled Sheet-Base (HRS-Base), Tugas Akhir Fakultas Teknik, Universitas Palangka Raya.

4. Craus, J, I. Ishai, and A. Sides, (1981), Durability Of Bituminions Paving Mixtures As Related To Filler Type And Properties, Proceedings Associations Of Asphalt. Paving Technologist, San Diego, Californnia, Vol, 50, pp. 291316, California.

5. Destarino (2019), Pengaruh Variasi Suhu Pemadatan Terhadap Tingkat Durabilitas Campuran Asphalt Concrete-Wearing Course (AC-WC), Tugas Akhir Fakultas Teknik, Universitas Palangka Raya Palangka Raya.

6. Direktorat Jendral Bina Marga (2019), Spesikasi Umum (Revisi 1), Jakarta.

7. Laranatha, D. (2003), Pengaruh Variasi Suhu Pemadatan Terhadap Campuran Hot Rolled Sheet (HRS), Tugas Akhir Fakultas Teknik, Universitas Palangka Raya.

8. Raharjo, B. (2016), Pengaruh Variasi Suhu Pemadatan Campuran Untuk Perkerasan Lapis Antara (AC-BC), Tugas Akhir Fakultas Teknik Lampung, Universitas Bandar Lampung.

9. Sitorus, F.H. (2018) Pemanfaatan Limbah Plastik Sebagai Bahan Tambah Campuran Aspal Pada Pekerasan Jalan AC-WC Terhadap Nilai Marshall, Tugas Akhir Fakultas Teknik Universitas Medan, Medan.

10. Sukirman, S. (2003), Beton Aspal Campuran Panas, Granit, Jakarta. 
11. Suprapto (2004), Fungsi Lapis Perkerasan, Jakarta.

12. Yahya, Y. (2019) Analisis Karakteristik Marshall Campuran Hot Rolled Sheet Wearing Course (HRS-WC) Menggunakan Bahan Tambah Plastik Bekas Jenis Polyethylene Terephthalate (PET), Tugas Akhir Fakultas Teknik Universitas Palangka Raya, Palangka Raya.

13. Yance (2017), Kajian Laboratorium Open Graded Asphalt (OGA) Menggunakan Agreggat Hampangen dan Bahan Tambah High Density Polyethylene dan Suhu Rendaman Yang Ditingkatkan, Tugas Akhir Fakultas Teknik Universitas Palangka Raya, Palangka Raya. 